\title{
Efficiency and Stability of Islamic Banking in ASEAN: DEA Window Analysis
}

\author{
Nailah$^{1} \&$ Aam Slamet Rusydiana ${ }^{2}$
}

\begin{abstract}
The study aims to analyze stability and efficiency of the Islamic banking industry in the Association of Southeast Asian Nations (ASEAN) region. Islamic banks are currently in the spotlight for their role in Islamic financial growth across South East Asia, especially in Indonesia. The efficiency and stability of Islamic banking is one factor in measuring the readiness of Islamic banks within the ASEAN Economic Community (AEC) framework. This research examines 12 Islamic banks in Indonesia, Malaysia, Brunei Darussalam and Thailand during the 2013-2018 period. The analysis was conducted with a non-parametric approach, namely DEA Window Analysis (DEWA). The results show that Malaysia has the highest average efficiency in four different periods with $96 \%$ and Indonesia has an average efficiency of $67 \%$. Thailand with an average efficiency that is relatively stable at $100 \%$ and Brunei Darussalam's average efficiency is 55\%, lower compared to other countries. For Islamic banks with good stability conditions are Bank Islam Malaysia Berhad and Islamic Bank of Thailand. Meanwhile, Islamic banks with unstable condition are Bank Mega Syariah and Bank Islam Brunei Darussalam. Overall, Islamic banks in ASEAN have achieved stable performance, even though most of them are still inefficient.
\end{abstract}

Keywords: Islamic Bank, ASEAN, DEA Window Analysis.

\begin{abstract}
Abstrak. Penelitian ini bertujuan untuk menganalisis stabilitas efisiensi pada industri perbankan syariah di ASEAN. Industri perbankan syariah saat ini sedang menjadi sorotan dalam pertumbuhan keuangan syariah di ASEAN, khususnya Indonesia. Efisiensi dan stabilitas pada perbankan syariah menjadi salah satu faktor dalam penilaian dalam kesiapan bank pada era Masyarakat Ekonomi ASEAN (MEA). Penelitian ini dilakukan pada 12 perbankan syariah yang berada di Indonesia, Malaysia, Brunei Darussalam dan Thailand pada periode 2013-2018. Analisis menggunakan pendekatan non-parametrik yakni metode DEA Window Analysis (DEWA). Hasil penelitian menunjukkan bahwa Malaysia memiliki rata-rata efisiensi pada 4 periode yang berbeda sebesar $96 \%$ dan Indonesia memiliki rata-rata efisiensi $67 \%$. Thailand dengan rata-rata efisiensi yang relatif stabil yaitu $100 \%$ dan Brunei Darussalam dengan rata-rata efisiensi 55\% lebih rendah jika dibandingkan negara lain. Untuk perbankan syariah yang memiliki stabilitas yang baik adalah Bank Islam Malaysia Berhad dan Islamic Bank of Thailand. Sedangkan, bank syariah yang berada pada kondisi tidak stabil adalah Bank Mega Syariah dan Bank Islam Brunesi Darussalam. Perbankan syariah di ASEAN secara stabilitas efisiensi bisa dikatakan sudah berada dalam kondisi stabil, meskipun dalam hal skor efisiensi yang dimiliki rata-rata masih berada pada kondisi yang tidak efisien.
\end{abstract}

Kata Kunci : Perbankan Syariah, ASEAN, DEA Window Analysis.

\footnotetext{
1 SEBI School of Islamic Economics, Depok | nailahrosyadi@gmail.com (Corresponding author)

2 Sharia Economic Applied Research E Training (SMART) Indonesia | aamsmart@gmail.com
} 


\section{Introduction}

The ASEAN Economic Community (AEC) was inaugurated in 2015, which was predicted to pose a threat to Islamic banking in Indonesia. AEC was alleged to affect the competitiveness of local Islamic banks vis-à-vis foreign banks that will enter Indonesia with their readiness to offer integrated financial services by 2020. Local banks will find it difficult to compete with foreign banks because they are able to offer more competitive and sophisticated services than what are offered by local Islamic banks (Rahmawati, 2015).

In 2016, business competition in the financial industry increased due to the existing of MEA agreement, including the banking industry with the ASEAN Banking Integration Framework (ABIF). Surely this has become an opportunity for Islamic banking in ASEAN countries, especially Indonesia in increasing opportunities for wider growth. Islamic banking can increase performance capacity and competitiveness so that it can operate efficiently (Fiafifah \& Darwanto, 2019). Efficiency measurement is one of important materials for evaluating the performance of Islamic banking in ASEAN with related parties and to compete in the ASEAN region and globally (Rodoni et al., 2020).

According to ICD Thompson Reuters (2019), The Southeast Asia region (ASEAN) ranked third in the world for the order of total assets of Islamic banks after the GCC and MENA in 2018. The total assets of Islamic banks in Southeast Asia are the US \$253 billion. Thus, the development of Islamic finance in Southeast Asia with the existence of Islamic banking institutions has contributed to the Islamic finance industry to achieve a better economy in Southeast Asia.

This is also reinforced by the Global Islamic Finance Report 2018, the Islamic finance industry in Malaysia ranked first with an index score of 81.21 on a scale of 100 . While Indonesia itself rose to 6 th place with an index score of 24.13 beating Pakistan (GIFR, 2018). As we know that Malaysia and Indonesia are part of the ASEAN countries. The results of the index scoring issued by 
GIFR made Malaysia a reference in developing the sharia financial industry for other countries. So that ASEAN is in the spotlight in terms of the development of the international Islamic finance industry.

The rapid growth of the Islamic finance industry makes Southeast Asia an important part of global Islamic finance. Where every country in ASEAN has its own variations in the development of Islamic banking. Malaysia is the fastest growing country in the development of Islamic banking in ASEAN countries. Indonesia is also active in the development of Islamic banking, although its development is slower than Malaysia. Besides these two countries, Brunei Darussalam is also intense in developing the Islamic banking industry. Furthermore, Singapore, the Philippines and Thailand are equally ambitious to develop this industry (Ghozali et al., 2019)

Islamic banking has an important role in the development of the Islamic financial industry in developing countries (Shawtari et al., 2018; Sufian \& Habibullah, 2012). The banking sector has a role in the transmission of monetary policy because there is no capital market. In contrast to developed countries, where banks perform simultaneously with the capital market in managing funds from customers.

In line with Rusydiana et al. (2019), the bank is an intermediary institution between the excess funds (surplus units) that store excess funds in the bank, and those who lack funds (deficit units) who borrow funds to banks. This intermediation function will affect the level of efficiency and optimal use of funds. The funds collected in the form of surplus units are then channeled by banks in the form of loans to deficit units in various forms of productive activities.

In this study, an analysis of the level of efficiency of Islamic banks was carried out using a non-parametric approach, namely the DEA Windows Analysis (DEWA). In addition to measuring the level of efficiency of Islamic banks in Southeast Asia, this study was conducted to see the level of efficiency stability in Islamic banks which were the object of research. So that we can find 
out the extent of resilience and competition that occurs between Islamic banks in ASEAN, especially Islamic banks in Indonesia.

The rest of the paper is organized as follows. The second section of the paper discusses the literature review, followed by the third section of methodology. Section 4 presents the results of the study and Section 5 concludes the paper.

\section{Literature Review}

The concept of efficiency starts from the concept of microeconomics, namely producer and consumer theory. Where producer theory stated that producers tend to maximize profits and minimize costs. Whereas the consumer theory stated that consumers tend to maximize their level of satisfaction (Ascarya \& Yumanita, 2006). So that the concept of efficiency is widely used to manage existing inputs into maximum output.

Sarjana (2009) indicated there are two kinds of efficiency, the technical efficiency and economic efficiency. Technical efficiency tends to the macroeconomic perspective, where technical efficiency tends to be limited to technical and operational relations in the process of converting inputs into outputs. While economic efficiency tends to the point of view of microeconomics, where prices are not considered unspecified, because prices will change following macro policies (Ascarya \& Yumanita, 2006)

The above three approaches can be used as a reference in determining input variables and output variables in measuring efficiency in Islamic financial institutions. Where in this study the subject is Islamic banks.

Although DEA in its standard version has been widely used in other studies, this study uses a different version of DEA, namely DEA Window Analysis (DEWA) to measure the efficiency of Islamic banking in Southeast Asia. DEA Window Analysis is one of the non-parametric methods used to estimate the performance of the Decision-Making Unit (DMU) compared to the frontier. This method has several advantages, where DEWA is able to evaluate the organization relative to benchmarks for a number of entities based on 
optimal performance theory for each organization. In addition, this method has no functional form and has the ability to use many inputs and outputs. This method is also superior and can help estimate the efficiency of DMU in a relative sense (Shawtari et al., 2018)

DEA Window Analysis works with the principle of moving averages and is useful for looking at trends in the performance of a unit over (Al-Delaimi \& Al-Ani, 2006; Zimkova, 2014). In analyzing the performance of a unit, DEWA treats each unit of the entity or organization as a different entity in each time period. Thus, this method is able to track the performance of a unit or process.

For example, if there are units with data in the form of inputs and outputs that are measured in different periods, then the total units need to be assessed simultaneously to capture variations in efficiency over time. Window analysis can also enable us to identify the best and worst sharia banks in a relative sense. So as to find out which Islamic banks are stable and variable in the DEA score.

Over time, the frontier efficiency model continues to experience growth, both in concept theory and practice. In general, the model of measuring the level of efficiency is divided into two namely parametric and non-parametric. Following are some previous studies which discussed the development of frontier efficiency models.

Al-Delaimi and Al-Ani (2006) studied 24 Islamic banking institutions using the DEA method. The aim is to measure and analyze the relative cost efficiency of Islamic banking. The results of this study show that the Islamic banking institutions that are sampled in this study have been efficient and can find ways to develop the efficiency they obtain.

Ascarya and Yumanita (2008) conducted a study with a comparative efficiency of Islamic banking in Malaysia and Indonesia. The results of the study explained the efficiency of banks in Malaysia reached 92\% efficiency scale. But overall efficiency is still at $74 \%$ because its technical efficiency is still low. Islamic banks in Malaysia only 40\% from 2002-2004, where only large Islamic banks tend to have higher efficiency than small ones. While recorded 
the highest efficiency value overall $85 \%$ due to an increase in the scale of good efficiency. However, technical efficiency is higher than Malaysia. The efficiency of Islamic banks in Indonesia has decreased from 86\% in 2002 to 58\% in 2005. Generally, the most efficient Islamic banks in Indonesia are long-standing banks.

Sufian and Noor (2009) measured the efficiency of banks in countries in the MENA region (Middle East and North Africa) and Asia. The results of this study indicate that Islamic banking in MENA shows a higher average technical efficiency level than Islamic banking in Asia. Thus, banks in the MENA region were found to be global leaders by dominating efficiency during the research period.

Rusydiana and Marlina (2019) measured the social and financial efficiency of Islamic banks in Indonesia in the 2013 to 2018 period. The results show that Islamic banks in Indonesia are socially efficient when compared to the value of financial efficiency. In addition, this study also shows that the average efficiency of the FDH (free disposal hull) model is higher than the efficiency of the CCR (CRS) and BCC (VRS).

Hadi and Saad (2010) in their research compared the level of efficiency of domestic and foreign Islamic banks in Malaysia. The result is the overall technical efficiency is $92.4 \%$ and $90.4 \%$ for domestic and foreign Islamic banks, respectively. The results show that the efficiency scale is dominated by the effects of pure technical efficiency in determining overall or technical efficiency for Islamic banks in Malaysia. This study also concluded that the performance of domestic Islamic banks is better than foreign Islamic banks in Malaysia.

Tai (2014) measured the efficiency and performance of 58 conventional and Islamic banks in the Gulf Cooperation Council (GCC). The result shows that Masraf Al-Rayan from Qatar is the most efficient bank and is an Islamic bank, while Kuwait Finance House (Islamic bank) is the most inefficient bank. Conventional banks are profitable, liquid and solvent in the initial research period, while Islamic banks experience the same conditions in the final research period. Regression results show that economic conditions, bank size, financial 
development, operating costs, and type of bank (conventional versus Islamic) are significant variables that affect ROAA.

Rosman et al. (2014) measured the efficiency of Islamic banks in Asian and Middle Eastern countries during the financial crisis in 2007 to 2010. Technically, the technical efficiency of Islamic banks in Middle-Eastern countries was operating on the wrong scale, so it is a major source of technical inefficiency. While Islamic banks in Asian countries the source of the inefficiency obtained is due to scale inefficiency, but the difference in the average efficiency of pure and scale technical is very small.

Another research was also conducted by Abdul-Wahab and Haron (2017) in measuring the efficiency of the performance of Islamic and conventional banking in Qatar. From this research, it is known that the efficiency of banking in Qatar has not shown optimal performance and requires improvement.

Furthermore, Zimkova (2014) measured the efficiency of bank in Slovakia during the period 2000-2012 using DEA Window Analysis in. The approach is based on the input variables (employee deposits, fixed assets of employee) while the output variables (income from fixed assets, including financing and investment in stock). From the results of the window analysis, it can be seen that the best performance efficiency was obtained by Slovenska sporitel'na and Tatra bank. The results obtained by banks in Slovakia based on the amount of assets are Slovenska sporitel'na with technical efficiency with a total of 5 years, while Tatra banks total of 4 years in the intermediation approach. On the contrary, the worst efficiency was Sberbank Slovensko, although the bank continued to improve performance during the analyzed period. Whereas for banks whose performance is unstable for technical efficiency with an intermediation approach is CSOB.

Shawtari, Kareem and Razak (2014) conducted research on the banking industry in Yemen during the period 1996-2011 using the DEA Window Analysis method. Research shows that the banking industry in Yemen experienced an overall downward trend and instability during the study 
period. This research also shows that the majority of conventional banks are more stable, while Islamic banks are more efficient over time.

The same study using DEA Window Analysis was conducted by Shawtari et al. (2018) which analyzes the efficiency of conventional and Islamic banks. The panel regression results show that the pure technical efficiency obtained by conventional banks is higher compared to Islamic banks. However, Islamic banks have more efficiency scale than conventional tires. Some factors that influence the type of efficiency are loans / financing, non-interest income / finance / liquidity and GDP. The influencing factors are formed differently both conventional and Islamic banks, depending on the factors that control them.

\section{Method}

The method used in this research is Data Envelopment Analysis (DEA). DEA is a non- parametric analysis method based on a linear programming approach in calculating the inputs and outputs to be compared. According to Wu et al (2006) DEA is one of the methods commonly used by researchers. This method is able to produce efficiency scores that reflect input and output variables (Yildirim, 2015).

Although DEA in its standard version has been widely used by researchers in general, this study uses a different DEA version, namely DEA Window Analysis (DEWA) to measure the efficiency score of Islamic banking in ASEAN. Non-parametric methods used to estimate the performance of the DMU are then compared. According to Campisi and Costa (2008), this method has several advantages including the ability to evaluate efficiency relative to benchmarks for a number of companies based on optimal performance for each organization. This method is superior and helps estimate the efficiency of DMU in a relative sense (Shawtari et al., 2018)

DEA Window Analysis works on the principle of moving averages which later detect the performance trends of each unit over time. Each DMU in a different period is processed like a different data. DMU performance in 
certain periods compared to other periods in the same DMU performance unit. This analysis can be used to increase the number of data points in the analysis, so that it can be used for smaller sample sizes. In using this DEWA there are variations that can be used, namely the number of time periods included in the analysis (in this study 3 years). This analysis can be used to observe a period of time, which covers the entire study period.

The object of study is the top 5 of Islamic banks in Indonesia, Malaysia, Brunei Darussalam, and Thailand based on total assets. For Brunei Darussalam, only one Islamic Bank publishes its annual financial report, while in Thailand, there is also only one Islamic bank in the country. All of them consist of 12 Islamic Banks with 72 annual financial reports (2013 - 2018). The samples in this study are presented in the table 1.

Table 1. Samples of Islamic Banks in ASEAN

\begin{tabular}{cll}
\hline No & Country & \multicolumn{1}{c}{ Bank } \\
\hline 1 & & Bank Muamalat Indonesia \\
2 & Indonesia & Bank Mega Syariah \\
3 & & Bank BNI Syariah \\
4 & & Bank Syariah Mandiri \\
5 & & Bank Islam Malaysia Berhad \\
6 & & Hong Leong Islamic Bank Berhad \\
7 & & CIMB Islamic Bank Berhad \\
8 & & Public Islamic Bank Berhad \\
9 & & RHB Islamic Bank Berhad \\
10 & & Bank Islam Brunei Darussalam \\
\hline 11 & Trunei Darussalam & Islamic Bank of Thailand \\
\hline 12 & Thailand & 12 \\
\hline
\end{tabular}

Input and output variable data are obtained from each bank's balance sheet and income statement. The author uses two input variables and two output variables to measure the efficiency and stability of Islamic bank efficiency. As input variables are Third Party Funds / Depossits (X1) and Total Assets (X2). Meanwhile for the output variables are Financing (Y1) and Revenue (Y2). The use of deposits and financing in input-output because this 
study uses an intermediary approach such as the research conducted by (Rusydiana, 2018). Table 2 explains the descriptive statistics of each input and output variable used in this study.

Table 2. Descriptive Statistics of Input and Output Variables

\begin{tabular}{ccccc}
\hline & \multicolumn{2}{c}{ Input (Million Rupiah) } & \multicolumn{2}{c}{ Output (Million Rupiah) } \\
Variable & Deposits & Assets & Financing & Income \\
\hline Mean & $78,669,293$ & $94,750,545$ & $55,838,828$ & $4,554,407$ \\
Max & $273,518,691$ & $340,635,793$ & $246,685,337$ & $15,584,911$ \\
Min & 34,718 & 31,731 & 15,810 & 1,219 \\
St. Dev & $66,614,029$ & $80,312,433$ & $61,828,007$ & $3,546,185$ \\
\hline
\end{tabular}

Analysis for efficiency measurements will be carried out twice. First, the calculation of efficiency with the CRS or CCR approach introduced by Charnes et al. (1978). Second, the efficiency calculation using the VRS or BCC approach was first introduced by Banker et al. (1984), then a window analysis of the BCC calculation results.

\section{Results and Discussion}

The study was conducted based on the results of the analysis of the DEA window of 12 Islamic banks in selected ASEAN countries. Based on Table 3 the efficiency value of CRS of Islamic banks in ASEAN in the period 2013 to 2018 experienced fluctuations. The overall efficiency value of sharia banks in ASEAN is relatively low at $63 \%$. This indicates that the performance of the Islamic banking industry in ASEAN is not good.

Based on the results of the CRS efficiency, the best performance owner based on the level of efficiency during the study period is RHB Islamic Bank Berhad with an average efficiency value of $85 \%$. The second best Islamic bank is CIM B Islamic Bank Berhad with an average efficiency value of $80 \%$. Next is the Islamic Bank of Thailand with an average efficiency value of $78 \%$.

Out of the three Islamic banks above, other Islamic banks have an average efficiency value above 70\%, namely Bank Islamic Malaysia Berhad (77\%), Public Islamic Bank Berhad (76\%) and Hong Leong Islamic Bank Berhad (75\%). The rest, other Islamic banks have an average value of efficiency below 
$70 \%$. Following below is the average efficiency of Islamic banks' CRS in ASEAN over the period 2013 to 2018.

Table 3. Islamic Bank CRS Efficiency Level in ASEAN 2013-2018

\begin{tabular}{lccccccc}
\hline \multicolumn{1}{c}{ Bank } & $\mathbf{2 0 1 3}$ & $\mathbf{2 0 1 4}$ & $\mathbf{2 0 1 5}$ & $\mathbf{2 0 1 6}$ & $\mathbf{2 0 1 7}$ & $\mathbf{2 0 1 8}$ & Mean \\
\hline BIMB & 0.78 & 0.62 & 0.79 & 0.78 & 0.81 & 0.81 & 0.77 \\
Bank Mega Syariah & 0.56 & 0.60 & 1.00 & 0.62 & 0.49 & 0.51 & 0.63 \\
BIBD & 0.57 & 0.49 & 0.58 & 0.36 & 0.37 & 0.39 & 0.46 \\
BMI & 0.48 & 0.44 & 0.49 & 0.61 & 0.55 & 0.48 & 0.51 \\
BNIS & 0.37 & 0.34 & 0.37 & 0.37 & 0.49 & 0.56 & 0.42 \\
BRIS & 0.40 & 0.39 & 0.42 & 0.51 & 0.46 & 0.45 & 0.44 \\
BSM & 0.35 & 0.29 & 0.35 & 0.37 & 0.38 & 0.39 & 0.35 \\
CIMB Islamic Berhad & 0.72 & 0.79 & 0.84 & 0.82 & 0.80 & 0.85 & 0.80 \\
HLB Islamic Berhad & 0.68 & 0.73 & 0.75 & 0.78 & 0.78 & 0.79 & 0.75 \\
Islamic Bank of Thailand & 1.00 & 1.00 & 0.79 & 0.77 & 0.54 & 0.57 & 0.78 \\
PIB Berhard & 0.72 & 0.72 & 0.74 & 0.81 & 0.78 & 0.79 & 0.76 \\
RHB Islamic Berhad & 0.69 & 0.75 & 0.86 & 0.89 & 0.94 & 0.96 & 0.85 \\
\hline \multicolumn{1}{c}{ Mean } & 0.61 & 0.60 & 0.67 & 0.64 & 0.62 & 0.63 & 0.63 \\
\hline
\end{tabular}

In addition, this study was also conducted based on a window analysis of 12 units of sharia banks in ASEAN as a consideration for other sharia banks. The results of the Window Analysis calculation table are used to analyze the stability of relative efficiency by using summary statistics such as standard deviation (SD), Long Distance per Window (LDW), Long Distance per Period (LDP) as well as Long Distance per Year (LDY). The above measurements can be used to measure the stability efficiency of each DMU. If the smaller the number of the four values above, the more stable the efficiency obtained per DMU.

Table 4 presents the results of the stability of the efficiency of Islamic banks in the ASEAN countries during the 2013-2018 period. As one example is the Bank Islam Malaysia Berhad (BIMB) which is experiencing almost constant conditions. This condition is seen in the first window, which is the period 20132015 where the efficiency values are 98\%, 100\% and 100\%. In 2013 to 2014, the efficiency value increased to $100 \%$ until 2015 . In contrast to the second window condition, the efficiency value obtained by banks tended to be more constant during the 2014-2016 period at 100\%. However, in the third window, the 2015 
TIFBR | Tazkia Islamic Finance and Business Review

Volume 14(1), 2020

2017 period, experienced a slight decline in 2015 to 2016, from an efficiency value of $100 \%$ to $98 \%$. But in 2017 the value of efficiency has again increased to $100 \%$. While in the fourth window, the 2016-2018 period, the conditions are not much different from the first window. BIMB also obtained a standard deviation of 0 which illustrates that BIMB's level of efficiency is relatively stable.

Table 4. DEA Window Analysis of Islamic Banks in ASEAN 2013-2018

\begin{tabular}{|c|c|c|c|c|c|c|c|c|c|c|c|c|}
\hline \multirow[b]{2}{*}{ IB } & \multirow[b]{2}{*}{ Window } & \multicolumn{6}{|c|}{ Efficiency Score } & \multicolumn{5}{|c|}{ Summary Measures } \\
\hline & & 2013 & 2014 & 2015 & 2016 & 2017 & 2018 & $\begin{array}{c}\text { Mean / } \\
\text { Window }\end{array}$ & $\begin{array}{l}\text { The } \\
\text { mean }\end{array}$ & SD & $\begin{array}{l}\text { LD } \\
\text { W }\end{array}$ & LDP \\
\hline \multirow{5}{*}{ BIMB } & W 1 & 0.98 & 1.00 & 1.00 & & & & 0.99 & \multirow{4}{*}{0.99} & \multirow{4}{*}{0.00} & \multirow{4}{*}{0.02} & \multirow{4}{*}{0.02} \\
\hline & W 2 & & 1.00 & 1.00 & 1.00 & & & 1.00 & & & & \\
\hline & W 3 & & & 1.00 & 0.98 & 1.00 & & 0.99 & & & & \\
\hline & W 4 & & & & 0.98 & 1.00 & 1.00 & 0.99 & & & & \\
\hline & LDY & $x$ & 0.00 & 0.00 & 0.02 & 0.00 & $x$ & & & $=0.02$ & & \\
\hline \multirow{5}{*}{$\begin{array}{c}\text { Bank } \\
\text { Mega } \\
\text { Syariah }\end{array}$} & W 1 & 0.56 & 0.60 & 1.00 & & & & 0.72 & \multirow{4}{*}{0.75} & \multirow{4}{*}{0.06} & \multirow{4}{*}{0.51} & \multirow{4}{*}{0.51} \\
\hline & W 2 & & 0.60 & 1.00 & 0.64 & & & 0.75 & & & & \\
\hline & W 3 & & & 1.00 & 0.64 & 0.49 & & 0.71 & & & & \\
\hline & W 4 & & & & 1.00 & 0.76 & 0.76 & 0.84 & & & & \\
\hline & LDY & $x$ & 0.00 & 0.00 & 0.36 & 0.27 & $x$ & & & $=0.36$ & & \\
\hline \multirow{5}{*}{ BIBD } & W 1 & 0.66 & 0.57 & 0.68 & & & & 0.64 & \multirow{4}{*}{0.55} & \multirow{4}{*}{0.06} & \multirow{4}{*}{0.23} & \multirow{4}{*}{0.24} \\
\hline & W 2 & & 0.57 & 0.67 & 0.44 & & & 0.56 & & & & \\
\hline & W 3 & & & 0.64 & 0.43 & 0.47 & & 0.51 & & & & \\
\hline & W 4 & & & & 0.49 & 0.53 & 0.50 & 0.50 & & & & \\
\hline & LDY & $x$ & 0.00 & 0.04 & 0.05 & 0.05 & $x$ & & & $=0.05$ & & \\
\hline \multirow{5}{*}{ BMI } & W 1 & 0.57 & 0.52 & 0.57 & & & & 0.55 & \multirow{4}{*}{0.72} & \multirow{4}{*}{0.13} & \multirow{4}{*}{0.44} & \multirow{4}{*}{0.44} \\
\hline & W 2 & & 0.52 & 0.57 & 0.96 & & & 0.68 & & & & \\
\hline & W 3 & & & 0.54 & 0.94 & 0.87 & & 0.78 & & & & \\
\hline & W 4 & & & & 0.95 & 0.86 & 0.76 & 0.86 & & & & \\
\hline & LDY & $x$ & 0.00 & 0.02 & 0.02 & 0.00 & $x$ & & & $=0.02$ & & \\
\hline \multirow{5}{*}{ BNIS } & W 1 & 0.40 & 0.38 & 0.42 & & & & 0.40 & \multirow{4}{*}{0.57} & \multirow{4}{*}{0.23} & & \\
\hline & W 2 & & 0.38 & 0.42 & 0.40 & & & 0.40 & & & 061 & 062 \\
\hline & W 3 & & & 0.41 & 0.39 & 1.00 & & 0.60 & & & & \\
\hline & W 4 & & & & 0.64 & 1.00 & 1.00 & 0.88 & & & & \\
\hline & LDY & $x$ & 0.00 & 0.00 & 0.25 & 0.00 & $x$ & & & $=0.25$ & & \\
\hline & W 1 & 0.46 & 0.45 & 0.48 & & & & 0.47 & & & & \\
\hline & W 2 & & 0.45 & 0.48 & 0.90 & & & 0.61 & 0 & 021 & 044 & 0,55 \\
\hline BRIS & W 3 & & & 0.47 & 0.89 & 0.90 & & 0.75 & & & & \\
\hline & W 4 & & & & 1.00 & 0.96 & 0.93 & 0.97 & & & & \\
\hline & LDY & $x$ & 0.00 & 0.01 & 0.11 & 0.06 & $x$ & & & $=0.11$ & & \\
\hline
\end{tabular}


TIFBR | Tazkia Islamic Finance and Business Review

Volume 14(1), 2020

\begin{tabular}{|c|c|c|c|c|c|c|c|c|c|c|c|c|}
\hline \multirow[b]{2}{*}{ IB } & \multirow[b]{2}{*}{ Window } & \multicolumn{6}{|c|}{ Efficiency Score } & \multicolumn{5}{|c|}{ Summary Measures } \\
\hline & & 2013 & 2014 & 2015 & 2016 & 2017 & 2018 & $\begin{array}{c}\text { Mean / } \\
\text { Window }\end{array}$ & $\begin{array}{l}\text { The } \\
\text { mean }\end{array}$ & SD & $\begin{array}{l}\text { LD } \\
\text { W }\end{array}$ & LDP \\
\hline \multirow{5}{*}{ BSM } & W 1 & 0.60 & 0.46 & 0.58 & & & & 0.55 & \multirow{4}{*}{0.63} & \multirow{4}{*}{0.09} & \multirow{4}{*}{0.22} & \multirow{4}{*}{0.37} \\
\hline & W 2 & & 0.46 & 0.58 & 0.68 & & & 0.57 & & & & \\
\hline & W 3 & & & 0.57 & 0.66 & 0.78 & & 0.67 & & & & \\
\hline & W 4 & & & & 0.64 & 0.78 & 0.82 & 0.75 & & & & \\
\hline & LDY & $x$ & 0.00 & 0.01 & 0.04 & 0.00 & $x$ & & & $=0.04$ & & \\
\hline \multirow{5}{*}{$\begin{array}{c}\text { CIMB } \\
\text { Islamic } \\
\text { Berhad }\end{array}$} & W 1 & 0.87 & 0.98 & 1.00 & & & & 0.95 & \multirow{4}{*}{0.97} & \multirow{4}{*}{0.03} & \multirow{4}{*}{0.13} & \multirow{4}{*}{0.13} \\
\hline & W 2 & & 0.97 & 1.00 & 1.00 & & & 0.99 & & & & \\
\hline & W 3 & & & 0.98 & 0.98 & 1.00 & & 0.99 & & & & \\
\hline & W 4 & & & & 0.92 & 0.89 & 1.00 & 0.94 & & & & \\
\hline & LDY & $x$ & 0.01 & 0.02 & 0.08 & 0.11 & $x$ & & & $=0.11$ & & \\
\hline \multirow{5}{*}{$\begin{array}{c}\text { HLB } \\
\text { Islamic } \\
\text { Berhad }\end{array}$} & W 1 & 0.85 & 0.90 & 0.93 & & & & 0.89 & \multirow{4}{*}{0.92} & \multirow{4}{*}{0.02} & \multirow{4}{*}{0.08} & \multirow{4}{*}{0.11} \\
\hline & W 2 & & 0.90 & 0.92 & 0.96 & & & 0.93 & & & & \\
\hline & W 3 & & & 0.90 & 0.94 & 0.95 & & 0.93 & & & & \\
\hline & W 4 & & & & 0.92 & 0.93 & 0.93 & 0.93 & & & & \\
\hline & LDY & $x$ & 0.00 & 0.02 & 0.04 & 0.02 & $x$ & & & $=0.04$ & & \\
\hline \multirow{5}{*}{$\begin{array}{c}\text { IB of } \\
\text { Thailand }\end{array}$} & W 1 & 1.00 & 1.00 & 1.00 & & & & 1.00 & \multirow{4}{*}{1.00} & \multirow{4}{*}{0.00} & \multirow{4}{*}{0.01} & \multirow{4}{*}{0.01} \\
\hline & W 2 & & 1.00 & 0.99 & 1.00 & & & 1.00 & & & & \\
\hline & W 3 & & & 1.00 & 1.00 & 1.00 & & 1.00 & & & & \\
\hline & W 4 & & & & 1.00 & 1.00 & 1.00 & 1.00 & & & & \\
\hline & LDY & $x$ & 0.00 & 0.01 & 0.00 & 0.00 & $x$ & & & $=0.01$ & & \\
\hline \multirow{5}{*}{$\begin{array}{c}\text { PIB } \\
\text { Berhad }\end{array}$} & W 1 & 0.90 & 0.90 & 0.94 & & & & 0.91 & \multirow{4}{*}{0.94} & \multirow{4}{*}{0.02} & & \\
\hline & W 2 & & 0.89 & 0.93 & 1.00 & & & 0.94 & & & 011 & 011 \\
\hline & W 3 & & & 0.91 & 0.98 & 0.95 & & 0.95 & & & 0.11 & 0.11 \\
\hline & W 4 & & & & 0.97 & 0.93 & 0.95 & 0.95 & & & & \\
\hline & LDY & $x$ & 0.01 & 0.03 & 0.03 & 0.02 & $x$ & & & $=0.03$ & & \\
\hline & W 1 & 0.86 & 0.95 & 1.00 & & & & 0.93 & & & & \\
\hline RHB & W 2 & & 0.94 & 0.99 & 1.00 & & & 0.98 & 96 & ? & 014 & 014 \\
\hline Islamic & W 3 & & & 0.92 & 0.98 & 1.00 & & 0.97 & & & & \\
\hline Berhad & W 4 & & & & 0.96 & 0.98 & 1.00 & 0.98 & & & & \\
\hline & LDY & $X$ & 0.01 & 0.08 & 0.04 & 0.02 & $x$ & & & $=0.08$ & & \\
\hline
\end{tabular}

In the same condition, the Islamic Bank of Thailand also received a standard deviation of 0 . The efficiency value obtained by the Islamic Bank of Thailand can be said to be very stable during the 2013-2018 period. Where almost all windows, the value of efficiency obtained every year reaches $100 \%$. Only in the second window, the 2014-2016 period experienced a slight decline in numbers, namely 0.01 in 2015 , but returned to $100 \%$ in 2016 . However, the 
change in the number did not significantly influence changes in the value of bank efficiency during the study period. This also illustrates that the Islamic Bank of Thailand is a bank that has good stability compared to other Islamic banks in ASEAN.

In addition, there are also Islamic banks whose efficiency values seen from the window analysis tend to be less stable. An example is Bank Mega Syariah which tends to fluctuate during the 2013-2018 period. In the first window it appears that the efficiency values tend to increase for 3 consecutive years ie $56 \%, 60 \%, 100 \%$. Different in the second window where the value of efficiency goes up and down ie $60 \%, 100 \%, 64 \%$. In the third window there is a decrease in the value of efficiency, namely $100 \%, 64 \%, 49 \%$. A similar condition occurred in the fourth window where the efficiency values obtained during the 2016-2018 period were 100\%, 76\%, 76\%. The standard deviation obtained by Bank Mega Syariah itself is 0.6 , wherein the condition can be said that the sharia bank still tends to be less stable.

Similar conditions occur in the Bank Islam Brunei Darussalam which is less stable and the average efficiency decreases every period. In the first window, BIBD obtained an efficiency value of $66 \%, 57 \%, 68 \%$. Then, in the second window for the 2014-2016 period the efficiency values were $57 \%, 67 \%$, $44 \%$. In the third window, BIBD began to experience a decrease in the value of efficiency, namely $64 \%, 43 \%, 47 \%$. The fourth window of the BIBD also did not change the value of efficiency significantly, namely at $49 \%, 53 \%, 50 \%$. In addition, BIBD has the same standard deviation obtained by Bank Mega Syariah which is equal to 0.6 .

From the overall analysis it appears that Islamic banking in Malaysia is relatively high in efficient value. Prior literature has suggested that larger banks tend to report higher levels of pure technical efficiency than their counterpart (Hadi \& Saad, 2010; Shawtari et al., 2018). Judging from the average efficiency per-period Malaysian banks have efficiency rates above $90 \%$. However, it is different from the results of research conducted by Faturohman et al. (2019), where Malaysia during the study period showed fluctuating efficiency values. 
Then subsequently, Thailand, there is an Islamic bank which is seen from 4 different periods, the efficiency value tends to be constant at $100 \%$, even though the input and output variables have a small number compared to other Islamic banks. But from these results it appears that the Islamic Bank of Thailand is able to minimize existing inputs in the form of productive activities and produce maximum output.

One of the factors that Malaysia has a high efficiency value compared to other countries in Southeast Asia is inseparable from the proportionality between input and output that is owned by Islamic banking in Malaysia. This condition is also supported by the long-standing establishment of Malaysian Islamic banking compared to other countries in Southeast Asia. In addition, support by the state government is based on government driven (Fakhrunnas, 2017). So that overall Islamic banking in Malaysia has the highest average efficiency value compared to other countries.

While the average efficiency obtained by Islamic banks in Indonesia is still below $70 \%$. However, each period the value of its efficiency has increased from $50 \%-80 \%$. The Islamic bank in Indonesia which has the highest efficiency value is Bank Muamalat Indonesia, which is $72 \%$. This is supported by research conducted by Rodoni et al. (2020) in measuring the efficiency of Islamic banking in ASEAN using the SFA method. The results show that during the study period, Bank Muamalat Indonesia obtained the highest average efficiency of 0.998460 among the 6 largest Islamic banks in each of these ASEAN countries.

In contrast to the results of research conducted by Alayya and Rani (2019) measuring the performance efficiency of Islamic commercial banks in Indonesia using the DEWA method. The results showed that BRI Syariah is the most efficient and stable bank from several other banks that were the research samples. In terms of utilizing company inputs in achieving maximum output levels, BRI Syariah can utilize inputs, namely TPF and labor costs to produce maximum output, namely financing and operating income.

Different conditions in Islamic banks in Brunei Darussalam, the average efficiency is still below $70 \%$, even each period tends to decline. The lower levels 
of pure technical efficiency could be due to the high level of concentration and the lack of competition in ASEAN banking sector. In addition, the efficiency at BIBD as a sharia bank in Brunei Darussalam the average efficiency obtained is below other countries in Southeast Asia. This is because Islamic banking in Brunei Darussalam is still growing less rapidly than other countries in Southeast Asia (Fakhrunnas, 2017).

The above conditions can be a reference for other Islamic banks in ASEAN to improve the efficiency and stability of their performance in the face of the MEA. Where Islamic banks that have high efficiency values can be a benchmark for other Islamic banks in improving efficiency. Islamic banks, in particular need to manage their inputs more efficiently by best allocating their inputs in order to have an optimal output due to rising competition across the globe (Zeitun \& Benjelloun, 2013). So that Islamic banks in ASEAN are able to compete both with national and foreign Islamic banks in their countries.

\section{Conclusion}

From the results of research conducted on 12 Islamic banks in Malaysia, Indonesia, Brunei Darussalam and Thailand by using the DEA Window Analysis, the level of efficiency of Islamic banking in ASEAN is still below the efficient value. The country with the highest average efficiency value is Malaysia with an average of $96 \%$ of the 5 Islamic banks that were sampled in the study. Then Indonesia from 5 Islamic banks that became an average sample of efficiency values are still below $70 \%$, which is $67 \%$. The Islamic bank that has the highest efficiency value is Bank Muamalat Indonesia, as a long-established Islamic bank. In addition, Thailand with the Islamic Bank of Thailand has a value of efficiency and conditions that are quite stable each period at 100\%. In contrast to Brunei Darussalam, with its BIBD, the average efficiency has decreased every period. When compared with other Islamic banks in ASEAN, the BIBD is an Islamic bank with the lowest average efficiency during the study period. 
Based on the stability of the window analysis conducted by Islamic banks which are in very stable condition is the Bank Islam Malaysia Berhad (BIMB) with the Islamic Bank of Thailand. While the sharia bank that is less stable is Mega Syariah Bank and the Bank Islam Brunei Darussalam (BIBD).

Therefore, these conditions need to be a concern for company management as well as the government, especially in Indonesia in measuring readiness to face the MEA period. In addition, this study still has limitations on the sample used in the study, not all Islamic banks in ASEAN are used as research. The sample is based on Islamic banks that have the highest total assets in the ASEAN countries that are the study population.

\section{References}

Abdul-Wahab, A.-H., \& Haron, R. (2017). Efficiency of Qatari banking Industry : an empirical Investigation. International Journal of Marketing, Vol. 35(2).

Al- Delaimi, K. S. K., \& Al-Ani, A. H. B. (2006). Using Data Envelopment Analysis To Measure Cost Efficiency With an Application on Islamic Banks. Scientific Journal of Administrative Development, Vol. 4: 134-156.

Alayya, U., \& Rani, L. N. (2019). Intertemporal Efficiency Analysis of Indonesian Sharia Commercial Bank after Spin off Period 2013-2017 : Data Envelopment Analysis (Window Analysis). 2nd International Conference on Islamic Economics, Business and Philanthropy (ICIEBP).

Ascarya, \& Yumanita, D. (2006). Mengukur Efisiensi Bank Syariah di Indonesia dengan Data Envelopment Analysis. TAZKIA Islamic Finance $\mathcal{E}$ Business Review, Vol. 1(2): 1-31.

Ascarya, \& Yumanita, D. (2008). Comparing The Efficiency of Islamic Banks in Malaysia and Indonesia. Buletin Ekonomi Moneter Dan Perbankan, Vol. 11(2): 95-119. https:/ / doi.org/10.1017/CBO9781107415324.004

Fakhrunnas, F. (2017). Efisiensi Perbankan Islam di Asia Tenggara. Jurnal Ekonomi \& Keuangan Islam, Vol. 3(1): 27-35. https://doi.org/10.20885/JEKI.vol4.iss1.art2

Faturohman, T., Maharani, A. K., Sudrajad, O. Y., \& Irawan, A. (2019). Data Envelopment Analysis (DEA) Efficiency of Islamic Banks in ASEAN : A Cross-Country Comparative Examination of intermediation and Production Efficiency Approach. Jurnal Ilmiah Manajemen Bisnis Dan Inovasi, Vol. 6(3): 163-187.

Fiafifah, A. L., \& Darwanto, D. (2019). Technical Efficiency Level of Islamic Bank in Indonesia. Al-Uqud: Journal of Islamic Economics, Vol. 3(2): 
114-132. https:/ / doi.org/10.26740/al-uqud.v3n2.p114-132

Ghozali, M., Azmi, M. U., \& Nugroho, W. (2019). Perkembangan Bank Syariah Di Asia Tenggara: Sebuah Kajian Historis. FALAH: Jurnal Ekonomi Syariah, Vol. 4(1): 44-55.

GIFR. (2018). Global Islamic Finance Report 2018.

Hadi, F. S. A., \& Saad, N. M. (2010). An Analysis on The Efficiency of The Malaysian Islamic Banking Industry: Domestic vs. Foreign. Review of Islamic Economics, Vol. 14(1): 27-47.

Rahmawati, R. (2015). Strategi Peningkatan Efisiensi Biaya pada Bank Umum Syariah Berbasis Stochastic Frontier Approach dan Data Envelopment Analysis. Buletin Ekonomi Moneter Dan Perbankan, Vol. 17(4): 457-480. https:/ / doi.org/10.21098/ bemp.v17i4.506

Rodoni, A., Medina, A. R., Yaman, B., \& Sopyan. (2020) Efficiency and Stability of Islamic Banking in ASEAN. Al-Iqtishad: Journal of Islamic Economic, Vol. 12(1): 63-76. https:// doi.org/10.15408/aiq.v12i1.14693

Rosman, R., Abd Wahab, N., \& Zainol, Z. (2014). Efficiency of Islamic Banks during The Financial Crisis: An Analysis of Middle Eastern and Asian Countries. Pasific-Basin Financial Journal, Vol. 28. 76-90.

Rusydiana, A. S. (2018). Efisiensi Dan Stabilitas Bank Umum Syariah Di Indonesia. Akuntabilitas: Jurnal Ilmu Akuntansi, Vol. 11(2): 203-222. https://doi.org/10.15408/akt.v11i2.7033

Rusydiana, A. S., Laila, N., \& Sudana. (2019). Efisiensi dan Produktivitas Industri Perbankan pada Sistem Moneter Ganda di Indonesia. Jurnal $\begin{array}{llll}\text { Siasat } \quad \text { Bisnis, } & \text { 23(1): }\end{array}$ https://doi.org/10.20885/jsb.vol23.iss1.art5

Rusydiana, A. S., \& Marlina, L. (2019). Financial and Social Efficiency on Indonesian Islamic Banks: A Non-Parametric Approach. Journal of Islamic Monetary Economics and Finance, Vol. 5(3): 579-602. https://doi.org/10.21098/jimf.v5i3.1154

Shawtari, F. A., Salem, M. A., \& Bakhit, I. (2018). Decomposition of Efficiency using DEA Window Analysis: A Comparative Evidence from Islamic and Conventional Banks. Benchmarking An International Journal, Vol. 25(6): 1681-1705. https:/ / doi.org/10.1108/BIJ-12-2016-0183

Shawtari, F. A., Kareem, M. A. A., \& Razak, S. H. A. (2014). Efficiency and Stability Assessment of the Yemeni Banking Sector Using Data Envelopment Window Analysis (DEWA). Proceedings of the 12th International Conference of DEA, 144-153. https:/ / doi.org/10.13140/RG.2.1.3353.2966

Sufian, F., \& Habibullah, M. S. (2012). Globalization and Bank Efficiency Nexus: Symbiosis or Parasites? Review of Development Finance, Vol. 2(3-4): 139-155. https://doi.org/10.1016/j.rdf.2012.09.003 
Sufian, F., \& Noor, M. A. N. M. (2009). The Determinants of Islamic banks' Efficiency Changes: Empirical Evidence from the MENA and Asian Banking Sectors. International Journal of Islamic and Middle Eastern Finance and Management, Vol. 2(2): 120-138. https:// doi.org/10.1108/17538390910965149

Tai, L. (2014). Efficiency and Performance of Conventional and Islamic Banks in GCC Countries. Middle East Journal of Business, Vol. 9(2): 60-71. https://doi.org/10.5742/mejb.2014.92387

Tuffahati, H., Mardian, S., \& Suprapto, E. (2019). Pengukuran Efisiensi Asuransi Syariah Dengan Data Envelopment Analysis (DEA). Jurnal Akuntansi Dan Keuangan Islam, Vol. 4(1): 1-23. https://doi.org/10.35836/jakis.v4i1.27

Yildirim, I. (2015). Financial efficiency analysis in Islamic banks: Turkey and Malaysia Models. Journal of Economics, Finance and Accounting, Vol. 2(3): 289-289. https://doi.org/10.17261/pressacademia.2015312956

Zeitun, R., \& Benjelloun, H. (2013). The Efficiency of Banks and the Financial Crisis in a Developing Economy: The Case of Jordan. Journal of Finance, Accounting and Management, Vol. 4(1): 1-20.

Zimkova, E. (2014). Window Analysis of Technical Efficiency: Case of The Slovak Banking System. 17th AMSE International Scientific Conference: 294-300. 